\title{
The Accessibility of Inclusive Schools in Surabaya
}

\author{
Muchamad Irvan, Muhammad Nurrohman Jauhari \\ Special Education Study Program \\ Faculty of Teacher Training and Education \\ University of PGRI Adi Buana Surabaya \\ irvan.mch15@gmail.com, muhammadnurrohmanjauhari@yahoo.co.id
}

\begin{abstract}
Inclusive education is a form of education that is currently being implemented by the government in providing educational services for all children without any limitations or discrimination. Basically, inclusive education has a philosophy of education and social form. Inclusive education in Permendiknas No. 70 in 2009 is defined as an educational system that provides opportunities for all students with special needs and has the potential for intelligence and / or gifted to attend education or learning in an educational environment together with students in general. As a form of implementation of special needs friendly inclusive education, inclusive schools have an obligation to provide accessibility. The method used in this study is descriptive with the type of survey method research. Descriptive statistical analysis techniques in this study use simple statistical calculations. Based on the results and the discussion above, we can see that every school in Surabaya has a percentage below $50 \%$, that is, with an average percentage of $19.97 \%$. This value is a very low value to measure the availability of accessibility of inclusive schools. Therefore, it can be concluded that inclusion schools in Surabaya still do not have the availability of accessible facilities and infrastructure for children with special needs.
\end{abstract}

Keywords-inclusive school; accessibility.

\section{INTRODUCTION}

Inclusive education is a form of education in providing educational services for all children without any limitations or discrimination Inclusive education is an integrated education where children with special needs can participate in obtaining education services with systems, methodologies, and learning that are appropriate to their needs and abilities [1]. Inclusive education in Permendiknas No. 70 in 2009 is defined as a system of education that provides opportunities for all students with special needs and has the potential for intelligence and/or special talents to attend education or learning in an educational environment together with students in general [2].

Inclusive school has to develop the values in terms of 3 dimensions, namely: 1) creating inclusive culture, 2) producing inclusive policies,3) evolving inclusive practices. Democracy is a cornerstone and founding value of the Swedish curricula and educational legislation. Fostering democracy and raising democratic citizens are principal functions of schools. However, the reality of the past two decades characterized by competition, efficiency, standardization and devolvement of responsibilities to local authorities has brought about divergent educational access and outcomes that, in turn, threaten the long tradition of equity, equality and solidarity. The social motives of education have lessened. Increased opportunities for school choice and increased residential segregation have contributed to growing disparities and differences between groups, not only in equality of access but also outcomes [3].

In the book Exceptional Children and Youth, basically children with special needs are children who experience intellectual, physical, social or emotional irregularities strikingly from what is considered growth and development normally, of course the person concerned cannot receive the maximum benefit from the public school program and require special classes or additional teaching and various services [4]. Classifications of children with special needs are 1). Deaf children (children who experience a lack or loss of ability to hear either partially or wholly due to the failure of some or all of the hearing devices, so that they cannot use their hearing instruments in a day-to-day life that has an impact on their lives in a complex manner); 2) Blind children (those who have limitations or even inability to receive stimuli or information from outside of it through their sense of vision); 3) Mentally retarded children (children who show intellectual function below the average clearly with an inability to adjust behavior and occur during development; 4) physically handicapped children (children who suffer from damaged or disturbed condition as a result of a form disorder or resistance to the bones, muscles, and joints in its normal function; 5) Autism Spectrum Disorder children (children who experience and have characteristics of disruption in social communication and social interaction accompanied by excessive behavior, limited interest and have a disruption in social reciprocity [5]. In general, Autism Spectrum Disorder children show their characteristics, namely the difficulty of socializing with peers or other people in the surrounding environment, unable to respond to an activity that is taking place around it [6].

For students with special needs in the Inclusion School environment, accessibility is everything that can facilitate them in accessing, obtaining services, and using every facility provided in the Inclusive School. It aims to get them the right to be independent and able to develop their potential. As a form of implementation of inclusive education that is friendly for students with special needs, inclusive schools have an obligation to provide accessibility.

Accessibility is the convenience provided for all people including children with special needs and the elderly in order to realize equal opportunities in all aspects of life and 
livelihood. As a provider of education services for children with special needs, it is the duty of the Inclusion School to provide accessibility for children with special needs [7]. The Inclusion School provides accessibility for children with special needs. Each building in the Inclusion School must have a special standard for each facility. Classrooms, supporting facilities, playgrounds, bathrooms, and access to any room must be adequate. Accessibility found in every detail of educational buildings and facilities is expected to be used as a demand so that every child with special needs can carry out activities independently in the school environment [8].

\section{METHOD}

Research studies that discuss the facts of the field in general can be referred to as survey research [9]. Concretely, researchers want to assess the accessibility services and various obstacles faced by inclusive schools in Surabaya. Therefore, the method used in this study is descriptive with the type of survey method research. Descriptive analysis techniques in this study use simple statistical calculations to help display the percentage of accessibility availability. The data obtained will be presented in the form of frequency and percentage to provide an overview of the distribution of subjects according to certain categories [10]. The populations in this study were all Inclusion Schools in Surabaya. While the samples in this study were taken randomly from elementary, middle and high school levels. As attitude in a study, the identity of each sample used in this study is kept confidential.

\section{RESULTS AND DISCUSSION}

Random samples were taken from each inclusion level of elementary, middle and high school in Surabaya. Some of the schools selected as research samples rejected for a number of specific reasons, so that researchers did re-election. The instrument used to assess the percentage of accessibility provided by inclusive schools for children with special needs was taken from the KEPMEN PU standard No. 30 of 2006 [7]. KEPMEN PU standard No. 30 of 2006 regulates the accessibility that must be provided now that the inclusion covers four principles of facilities and accessibility, namely Safety, Ease, Use and Independence [7]. There are 12 facilities and infrastructure that should be provided by inclusive schools as a form of accessibility services for children with special needs, while the facilities and infrastructure include availability of Crutches, Handrails, Ram, Bathrooms, Wheelchair, Guiding Block, Braille Posts, Sticks of the Blind, Reglet and Stylus, Special Space, Special Doors, and Special Parking.

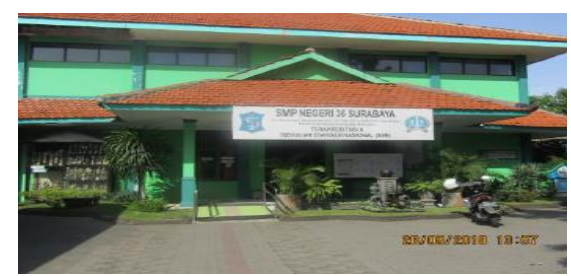

Fig. 1. Ramp at inclusive school

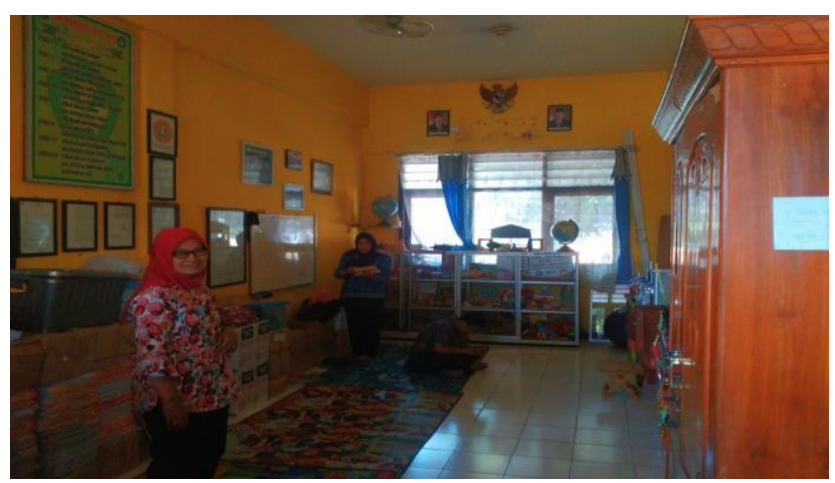

Fig. 2. Source space at inclusive school

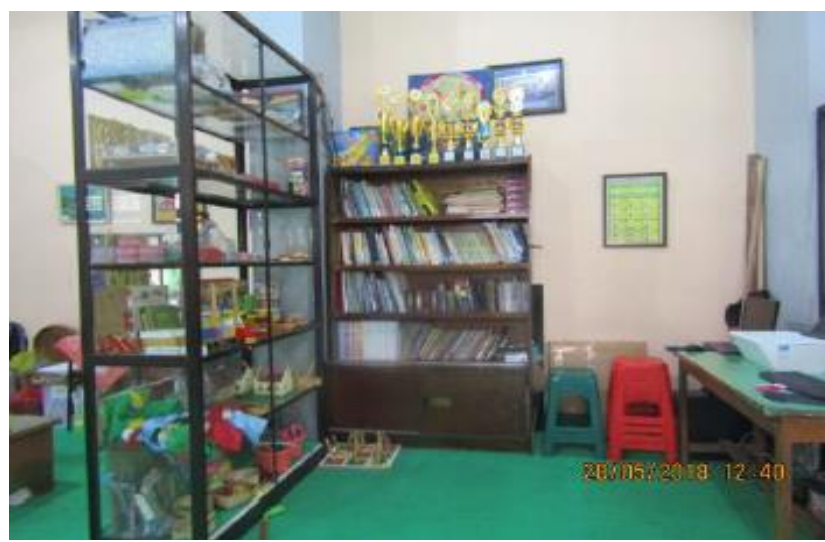

Fig. 3. Special space at inclusive school

Based on the survey analysis conducted by researchers in 15 schools showing, the result shows the following percentages:

TABLE I. PERCENTAGES AVAILABILITY OF ACCESSIBILITY IN INCLUSIVE SCHOOLS

\begin{tabular}{|l|l|}
\hline \multicolumn{1}{|c|}{ School } & \multicolumn{1}{c|}{ Accessibility } \\
\hline SDN A & $16,6 \%$ \\
\hline SDN B & $8,3 \%$ \\
\hline SDN C & $25 \%$ \\
\hline SDN D & $25 \%$ \\
\hline SDN E & $33,3 \%$ \\
\hline SMPN A & $8,3 \%$ \\
\hline SMPN B & $25 \%$ \\
\hline SMPN C & $33,3 \%$ \\
\hline SMPN D & $8,3 \%$ \\
\hline SMPN E & $25 \%$ \\
\hline SMA A & $33,3 \%$ \\
\hline SMA B & $8,3 \%$ \\
\hline SMA C & $8,3 \%$ \\
\hline SMA D & $16,6 \%$ \\
\hline SMA E & $25 \%$ \\
\hline
\end{tabular}

The table above shows the percentage of accessibility in Inclusive schools. It can be observed that all schools that have taken as the research sample have a percentage below $50 \%$. The data can be described in the following diagram: 


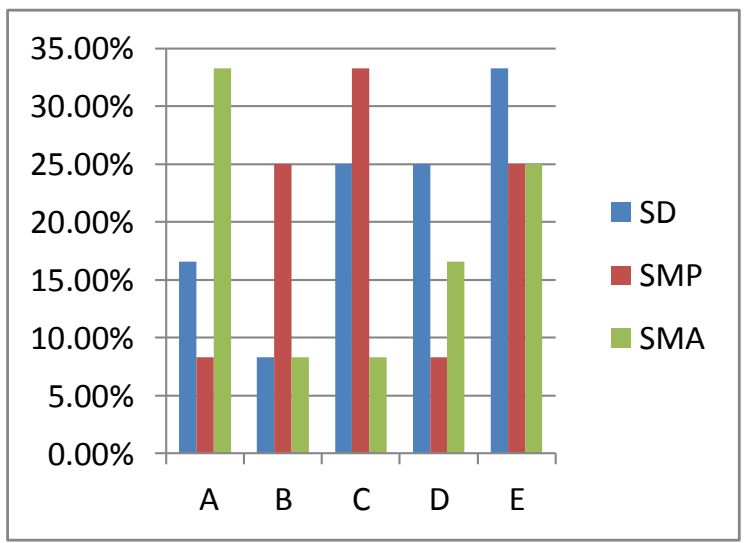

Fig. 4. Percentages availability of Accessibility in inclusive schools

Based on the percentage value shown, the average calculation of the percentage of accessibility availability is $19.97 \%$. A value of $19.97 \%$ is a very low number to show that a school is ready to implement inclusive education. The statement refers to that an inclusive school must be able to provide a friendly environment for student with special needs, namely by demonstrating the availability of adequate accessibility.

The lack of accessibility in inclusive schools in Surabaya has several reasons referring to the results of interviews conducted by researchers on the teachers appointed as the respondents. There are 2 main reasons expressed by respondents: (1) There is no budget available from the government to improve accessibility; (2) The readiness of schools designated as inclusive schools is less mature. Some schools have difficulty in providing accessibility for students with special needs due to the lack of budget owned by the school. Providing accessibility needs a considerable renovation in the school building, therefore the main obstacle in implementation is cost. However, the government in particular still has not provided a budget for schools designated to organize inclusive education to renovate buildings to be more accessible. The next reason is about the readiness of the school appointed to organize inclusive education. In this case, the government appoints certain schools without providing special preparation in material and non-material forms. The material preparation in question is a means of infrastructure related to accessibility, while nonmaterial is the teacher's knowledge and resources.

Accessibility must be found in every detail of educational buildings and facilities, with the aim that each child with special needs can carry out activities independently in the school environment [8]. This is in line with the aim of inclusive education, namely to make children with special needs have the same position as other children [11]. Accessibility also has an important role in achieving the goals and benefits of implementing inclusive education. Based on result of data analysis, it can be concluded that inclusion schools in Surabaya still do not have the availability of accessible facilities and infrastructure for students with special needs

\section{CONCLUSION}

Based on the results and the discussion above, we can see that every school in Surabaya has a percentage below $50 \%$, that is, with an average percentage of $19.97 \%$. This value is a very low value to measure the availability of accessibility of inclusive schools. Therefore, it can be concluded that inclusion schools in Surabaya still do not have the availability of accessible facilities and infrastructure for students with special needs. Reflected form the result of this study, it is suggested that the government needs to pay more attention and provides accessibility in inclusive schools in order to create a special needs friendly culture and environment.

\section{REFERENCES}

[1] O. Abosi, and T. L. Koay, "attaining development goal of chldren with disabilities: implication for inclusive education," International Journal of Special Education, vol. 23, no. 3, 2008.

[2] P. M. P. Nasional, and R. INDONESIA, Pendidikan inklusif bagi peserta didik yang memiliki kelainan dan memiliki potensi kecerdasan dan/atau bakat istimewa, 2009.

[3] G. Berhanu, "Inclusive education in Sweden: responses, challenges and prospects," International journal of special education, vol. 26, no. 2, pp. 128-148, 2011

[4] W. M. Cruickshank and G. O. Johnson, Eds., "Education of exceptional children and youth.," 1958.

[5] V. A. Arlington, Diagnostik and stastitical manual of mental disorder, fifth edition (DSM 5), Washington. American Psychiatric Assosiation, 2013.

[6] W. Kauffman, Symphosium: The new diagnostig criteria for autism spectrum disorder, Harvard: Departement of Neurology Boston Children's Hospital.Harvard Medical School, 2013.

[7] P. M. P. U. (30). No, Tahun 2006 tentang Pedoman Teknis Fasilitas dan Aksesibilitas pada Bangunan Gedung dan Lingkungan, 2006.

[8] N. A. Widi, and R. Nirwansyah, "Penerapan aksesibilitas pada desain fasilitas pendidikan sekolah luar biasa," Jurnal Sains dan Seni ITS, vol. 2, no. 2, pp. G20-G25, 2013.

[9] S. Sugiyono, Metode penelitian kuantitatif, kualitatif, dan R\&D, Bandung: Alfabeta, 2009.

[10] L. J. Moleong, Metodologi penelitian kualitatif, Bandung: Mandar Maju, 2007.

[11] H. Widyastono, "Penyelenggaraan pendidikan inklusif bagi anak berkelainan," Jurnal Pendidikan Dan Kebudayaan.Jurnal Pendidikan Dan Kebudayaan, vol. 10, no. 046, 2004. 